\title{
Thoughts on the Use of "le" in Teaching Chinese to Speakers of Other Languages: Problems and Suggestions
}

\author{
Sen Chen 1,2, Roula Tsokalidou ${ }^{2,3}$ \\ ${ }^{1}$ Shanghai International Studies University, Shanghai, China \\ ${ }^{2}$ Confucius Institute at Aristotle University of Thessaloniki, Thessaloniki, Greece \\ ${ }^{3}$ Aristotle University of Thessaloniki, Thessaloniki, Greece \\ Email:chen.sen@hotmail.com
}

How to cite this paper: Chen, S., \& Tsokalidou, R. (2021). Thoughts on the Use of "le" in Teaching Chinese to Speakers of Other Languages: Problems and Suggestions. Open Journal of Social Sciences, 9, 610-627.

https://doi.org/10.4236/jss.2021.99045

Received: August 26, 2021

Accepted: September 26, 2021

Published: September 29, 2021

\begin{abstract}
Within the context of Teaching Chinese to Speakers of Other Languages (hereafter TCSOL), the teaching of "le" is a key and thought-provoking grammatical point. Holding the view that the general explanations, often used in textbooks, are not easy for students to comprehend, after studying the relevant literature and drawing examples from specific textbooks, we make some suggestions regarding the teaching of "le". The innovation of this article is the proposal of a unified approach to the interpretation of "le" within the theory of "realization", the avoidance of the concepts of "complete" and "change", of " $l e_{1}+l e_{2}=l e_{3}$ " and of the idea that " $l e_{2}$ " indicates the "tone". Simultaneously, we propose the increase of the subjective communicative uses of "le", the distinction between the meanings of sentence patterns and word meanings, and the unification of related terms.
\end{abstract}

\section{Keywords}

Chinese, The le Particle, TCSOL

\section{Introduction}

There is no definite conclusion about the research of " $l e$ " in the field of linguistics. However, many reference books consider its functions to indicate "the realization or the completion of an action", "affirmation of the realization or completion of an action" and "the emergence of changes or new circumstances" (for instance, see New Practical Chinese Reader).

The interpretation of " $l e$ " in current international Chinese textbooks generally cannot solve the issues raised in examples like the following: “大家安静一下, 我 
们上课了”, “这个你当然懂了”. The uses of “le" here do not refer to completion, affirmation of completion, or the emergence and change of the situation. Hence what does "le" refer to?

In “等你去了就知道了” the first “le" means completion but what does the second "le" mean? Is it the emergence of a new situation or an affirmation of completion? How to explain this “affirmation” to students? “这个老师最好了”, what does “le" mean here? What is the difference between “老师, 我昨天晚上看 了电视了”, “老师, 我昨天晚上看了电视” “老师, 我昨天晚上看电视了”? “到 动物园看了熊猫, 我们很高兴了”, Doesn't the “le” at the end of the sentence mean "affirmation that the behavior has been completed"? Why is it grammatically wrong then?

Based on this, the purpose of writing this article is to integrate the ideas of previous scholars, to think about the problems existing in TCSOL and to ultimately suggest ways of improving the teaching and learning process. The difference between a pedagogically-oriented grammar and a general grammar is that the explanatory power of the first one needs to be stronger, aiming to facilitate the students' understanding. This article will start with a discussion of these issues, i.e. the features of "le", the problems existing in current international Chinese textbooks and it will make some suggestions.

\section{The Features of "le"}

\subsection{Basic Consensus}

The definition of "le" in the part-of-speech system of Huang and Liao's "Modern Chinese" (Sixth Edition) is:

1) Aspectual particle. Used after verbs and adjectives, it means the realization of actions or behaviors has become a fact. "This feature is usually called " $l e_{1}$ ".

2) Modal particles. The function of modal particles is to express the mood, which is mainly used at the end of a sentence, and can also be used in a sentence where there is a pause after the subject and the adverbial. The tone of "le" means declarative tone, imperative tone, "represents the emergence of new situations" and "help complete a sentence". This feature is usually called " $l e_{2}$ ".

3) When used continuously at the end of the sentence, such as “自行车他骑走 了”, “枫树的叶子红了”. The “le” at the end of this sentence not only indicates the realization of the behavior, but also the change of the state of affairs. Some people categorize this use as " $1 e_{3}$ ".

The above points can be said to be the basic consensus in the relevant academic field. However, apart from these common distinctions, there are also some different points of view.

\section{2. $l e_{1}$}

Discussions on the "le" focus on the following: Firstly, does it really show the "realization" or "completion" aspect? Secondly, what are the conditions of its use? That is, under which circumstances should it be used, when can it be used 
and when should it not be used? Thirdly, what is the relationship between it and the concept of "tense"? We will discuss these questions below.

Regarding the first question, that is, whether it really means the "realization" or "completion" of actions, native English speakers have a perfect aspect in their mother tongue. They can easily associate the concept of "completion" with reference to their own language. In fact, there are some actions in Chinese that have not been completed even though "le" has been added. Liu (1988) does not agree with the "completion" theory, but believes that " $e_{1}$ " is a marker of "realization", indicating that the meanings of verbs, adjectives and other predicate forms are in a state of fact. Although in sentences like “说了就放心了” “吃了就 走”, “le" actually means completion, “le" in the two examples of “低了头” and “红了脸” can be replaced by “zhe" without changing the meaning: “低着头” and “红着脸”. The point is that the “低” and “红” actions are not over, but they are in progress. Other examples such as “疯了许多年”, “终于过上了好日子”, “打了 起来”, etc. are also the same. Based on this, Jin (2002) started from the semantic types of verbs, and further proved the three situations of the corresponding action states: “吃” (weakly action-continuous verbs) plus “le" and the behavior was implemented. When "le" comes after strong action-continuous verbs, such as “了解”, the behavior is implemented and continues and in non action-continuous verbs or adjective, such as “死" and “红” the use of "le" indicates that the behavior has been achieved and the changed state continues to hold. In addition, the article also examines the situation of " $\mathrm{V}+l e+\mathrm{O}$ " with a time period attributive and a subject. It is proved that the particle " $l e_{1}$ " works with other syntactic conditions to give the verbs "end continuation", "behavior continuation" and "state continuation". In summary, "realization" includes "completion". Regardless of whether the action ends or the stage the action has reached, the premise is that it has been "realized", otherwise there is no way to talk about it. So obviously "realization" is a more general term. Wang \& Huang (2020) believe that "le" shows that the whole or a phase of the internal process of the action or state has reached the end. In fact, it is consistent with the term "realization".

Regarding the second point, concerning the conditions of its use, Fan (2020) examined in detail the " $l e_{1}$ " distribution conditions, suggesting that its use is influenced by at least five grammar factors: the reality of the situation predicate, the predicate syntactic status, the situation of the sentence particles, the types of objects and the types of verbs. In this regard, it is believed that " $l e_{1}$ " is a tense marker that marks the time of an event and its use will naturally be subject to the temporal attribute of the predicate-that is, the reality (Fan, 2020: 192).

Regarding the third point, the relation of "le" with "tense", Lin (2017) believes that " $l e$ " is not a mere aspect marker, but a marker that combines past tense and aspect meaning. The "time" here refers to the meaning of "relative past tense". In fact, this could correspond to the English future perfect tense (will have done something). For example, “明天这个时候,她应该早就抵达了洛杉矶” The absolute time that time occurred is “明天这个时候”, but the action of “抵达” oc- 
curred before that. The author believes that although Chinese still doesn't have a truly grammatically mature tense system, perhaps the aspectual marker will evolve into a tense marker in the future, "le" being a good example of this prospective process.

\section{3. $l e_{2}$}

The discussion of "le $e_{2}$ " in academia is mainly focused on: 1) How to understand the three prevailing interpretations, i.e. "changes or new situations appear", "confirmation tone, which means that things are done or realized" and "the function of forming sentences?" 2) "What are its subjective interactivity usages? 3) What is the law of co-occurrence with " $l e_{1}$ "? 4 . What is its relation with "tense" and "aspect"? We will discuss these separately below.

\subsubsection{Changes, Tone and New Circumstances}

Liu (2002) believes that people's expression of the function of " $l e_{2}$ " as "representing change" is too simplistic. This explanation can be used for general sentences, such as “下雨了”, which carries the meaning of a situation changed compared to its previous state. From a cognitive perspective, the reason for this interpretation of "le" is that it corresponds to the listener's background information at a given point of time. The presupposition of “下雨了” is “it didn't rain till just now", so this is a change. The "le" sentence in this case does not show the former state, only the latter one. However, the following three sentences do not seem to be perfectly explained:

Sentence 1. “老师, 我昨晚上看电视了。”

Sentence 2. “太善良了。”

Sentence 3. “吃饭了! 吃饭了!”

If not specifically pointed out, many students think that the "new situation" refers to the time when the speaker is speaking. “下雨了” can easily be understood as based on the time when the speaker is talking (that is, now). “下雨了” this new situation appears. But it is not limited to the current situation. For example “我去年去德国了” (I haven’t been there before) “我那时候厉害多了” (I am not so great now). Therefore, this so-called "new situation" actually means new information that the speaker knows but the listener doesn't know. According to the "cooperative principle" of speaking (Grice, 1989), effective conversation should generally express a balance between quantity, quality, relevance and manner. In this light, a lot of conversation aims to provide new information. The reason why people think that this "new situation" has just happened is because it fits most situations in life in terms of pragmatic frequency, but this is just a coincidence. Therefore, from the perspective of conversation and communication, the use of "le" shows only that what this sentence says is a new state of affairs, possibly unknown to the listener. So the above three examples can be interpreted as:

Sentence 1 . The student provided the teacher with information that the teacher did not know before: He watched TV yesterday. 
Sentence 2. "Kindness" exceeds a comparison standard in the mind of the speaker and "too kind" exceeds the comparison standard. This is essentially the provision of new information. It can be used in different contexts to express different intentions, such as “他真的太善良了! ” and “唉, 我真是太善良了, 才 会被他骗”. So “tai + adjective $+l e$ " is superficial. It seems that the so-called "change" aspect is lost, but it can still be explained within its paradigm.

Sentence 3. The pragmatic meaning here is to remind everyone that it's time to eat. Liu (2002) believes that this is a phenomenon similar to the English sentence "I am going to do something", placing the progressive aspect in advance. The purpose of "le" here is also to report a new state of affairs. However, this new state has not happened yet, but it is expected to happen soon. Therefore, we can say that the usage of " $l e_{2}$ " is to provide new information that the listener does not have. Regarding the interpretation of such sentences, below, we will discuss them from the perspective of subjective communicativeness.

In addition, does it express the tone of a statement used to affirm the completion or realization of things? In fact, this argument includes two parts: the "aspect" at a syntactic level and the "statement" at a discourse level. Wang \& Huang (2020) define " $l e_{2}$ " as aiming to "affirm that the objective state of affairs has changed or the subjective tone and state of affairs will change." This definition is rather vague, as it is difficult for learners to use this definition to compare and distinguish " $l e_{2}$ " from " $l e_{1}$ ", since both of these centre around the concept of change. So what is the difference between the two uses of "le"? He (2013) also pointed out that with regard to " $l e_{2}$ ", if we say that it means a statement, then we have to be able to explain enough issues and cover enough phenomena. For example, “门是开的” and “门开了” are both statements. Why does one use “le" and the other not? In his article $\mathrm{He}$ (2013) explained the subjectivity and openness of " $l e_{2}$ " from the four perspectives of "le $e_{\text {change }}$ ", " $I e_{\text {knowledge" }}$ ", " $/ e_{\text {determination }}$ " and " $l e_{\text {sensation }}$ " and suggested an answer to this question. For the same communicative purpose, we can choose to use "le" or not use "le". There must be a difference. This difference is the "time axis" and "space axis" with "le" (that is, the “change” meaning). For example, the sentence “你要吃你吃吧! 我不吃了。” Of course, we can say that "le" here means change, but this is not the main message conveyed by the speaker. The main message should be an expression of attitude. This is the interpretation from a subjective point of view. Concerning the difference between " $l e_{2}$ " and " $e_{1}$ ", when speakers start a sentence with " $l e_{2}$ ", they place a meaning "point" on the "axis" and this point is more prominent and not isolated, so it has the possibility of movement, change, connection and demarcation, contrast, while, in contrast, the " $1 e_{1}$ " is static. Using this theory to explain" 他在北京住了三年” and “他在北京住了三年了”, we can see that because the second sentence has " $l e_{2}$ ", it is open in the timeline, so people tend to think that he is still living in Beijing now.

Secondly, does "le" have the function of forming sentences? This is also a very mysterious concept in TCSOL and students often do not grasp it well. Why can't “吃了苹果” be an independent sentence, but “吃了苹果了” can be a complete 
sentence? Scholars have explored and explained different aspects such as "tense", "tone" or "subjectivity". From the point of view of semantic structure, syntactic hierarchy, tone structure and the absence of tense markers, Wang \& Huang (2020) found as the reasons that " $1 e_{1}$ " has less the capacity of the " $l e_{2}$ " in terms of forming sentences.

“喝了酒” is a phrase, not a sentence, while “喝酒了” is a sentence, treating the "tone" component of " $l e_{2}$ " higher than a VP. The tone structure has an important restriction on the ability of the two "le" uses to form sentences. Wang \& Huang (2020) adopt the view that Chinese sentences have two related markers: intonation and modal particles at the end of the sentence. Intonation is a mandatory marker, giving priority to the sentence with a speech act mood, while the modal particle is an optional marker, while a range of indirect tone of voice is given on top of the speech act mood given by the intonation, which indicates the present subjectivity and interactive subjectivity of the speaker. The reason for mentioning this is that in western languages there is often a restricted range of modality, ie tone and some other means. The tone structure here is the so-called "sentence-forming function". Thus, the article claims that, in the sentence where " $l e_{1}$ " and " $l e_{2}$ " co-occur, the reason why " $l e_{1}$ " is often free to disappear is because " $e_{2}$ " has already admitted that the events have happened. Moreover, the tone structure which " $l e_{2}$ " participates in "almost possesses unlimited sentence-making ability". The three categories of tense, aspect and mood have their own emphasis in human language. Chinese is a "highlight on aspect" and "highlight on tone" language, which corresponds to " $l e_{1}$ " and " $l e_{2}$ ", respectively. The reason why " $\mathrm{V}$ $+l e_{1}$ " cannot become a sentence is the absence of the tense marker. Similarly, Liu (2002) also gave an explanation from the perspective of tense, suggesting that "V $+l e+\mathrm{O}$ " only has an aspect marker and no tense marker, therefore it can not constitute an independent sentence. In order to solve this contradiction, Chinese has to resort to the use of "le" again. When there is no time word, the behavior belongs to the past. The premise of this statement is that "le $e_{2}$ " can have the function of "tense" marking. This function enables " $\mathrm{V}+l e+\mathrm{O}$ "to become a complete sentence. For example:

\section{吃了饭再去 (future tense) 吃了饭了 (past tense)}

Offering a different approach to the tense perspective by other scholars, $\mathrm{He}$ (2013) uses "subjectivity" to explain the sentence-forming function of " $l e_{2}$ ". For example:

“今天热死” cannot be formed into a sentence alone, but “今天热死了” can be a sentence because it puts the meaning in a prominent position on the "sensation axis".

\subsubsection{Subjective Interactivity Usages}

If we follow the existing argument, we seem to be unable to explain the usage of “ $l e$ ” in “这个老师最好了” and “吃饭了”. The “ $l e$ ” in these two sentences does not mean a change, nor does it mean that an action has occurred. On this point, Xiao \& Shen (2009) explained the subjectivity of " $l e_{2}$ " in detail, which we con- 
sider more convincing. This paper presents the three uses " $/ e_{\text {behavior }}$ " $/ e_{\text {knowledge" }}$

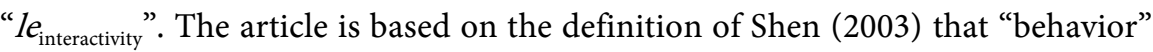
refers to actual behavior or action and "knowledge" refers to subjective perception and cognition, which is related to the state of knowledge of the speaker or listener, that is, the state of knowledge. "Interactivity" refers to the verbal act used to realize a certain intention, such as commands, promises, requests, etc. Based on this theoretical framework, " $l e_{2}$ " is divided into three categories. All three usages indicate the emergence of a new situation. This puts the traditional meaning of " $l e_{1}$ " and " $l e_{2}$ " in the same framework. The following examples are " $l e_{\text {interactivity }}$ ". These sentences represent a decree, requests, promises, advice, questions and other functions. We can summarize such sentences as "I say [P] $1 \boldsymbol{e}$ ", where "say" is a generalization of many similar words:

$\begin{array}{ll}\text { 快点了 (Expressing urging) } & \text { 别去了 (Recommendation) } \\ \text { 再见了 (Indicating promise) } & \text { 再见了 (Express “please”) }\end{array}$

再见了 (Indicating promise) 再见了 (Express “please”)

The following examples are all "le $e_{\text {knowledge }}$ ". These sentences often have the emotional color of the speaker. Recognition, speculation, inference, conjecture, evaluation, etc. We can sum it up as "I think [P] le." The "think" in it is a generalization of many similar words:

看来你就是陈老师了。

我最喜欢学习汉语了。

Deng (2021) focused on the "interactive subjectivity" of the pragmatic category, refined the "le $e_{\text {interactivity" }}$ and added a "Please listen to me" principle, which greatly enhanced the explanatory power. The author holds the view that the nature of subjectivity is an interaction between speaker and hearer. He pointed out that previous studies on the various pragmatic functions of " $1 e_{2}$ " claim that it has internalized its semantic function, so it can be used directly without contextual explanation. Wang and Huang (2020) also believe that " $l e_{2}$ " is strongly subjective. He (2013) also starts from the perspective of "subjectivity", enumerating the four cases of "time-space axis", "knowledge axis", "will axis", and "sensation axis". We believe that the above-mentioned research which focuses on communication and on the pragmatic level, not on the syntactic level, has an advantage over other theories in terms of the explanatory power of some speech phenomena.

\subsubsection{Rules of Co-Occurrence}

Regarding the third point, that is the rules of co-occurrence with " $1 e_{1}$ ", Wang \& Huang (2020) analyse it from the perspective of "tone". He (2013) also believes that when " $l e_{1}$ " and " $l e_{2}$ " co-occur, each has its own responsibility. Fan (2020) adopting a different angle, specifically describes the restrictions on the use of " $/ e_{1}$ " at the end of the sentence. The phenomenon that Liu (2002) mentioned as belonging to the Beijing dialect, " $\mathrm{V}+l e+\mathrm{O}+l e$ " is gradually changing to " $\mathrm{V}+$ $\mathrm{O}+1 e$ ". He thinks that this is due to the fact that the "le" at the end of the sentence indicates the past tense, that is that the action has been naturally completed, so the previous " $l e$ " is omitted. We think that the omitted " $l e_{1}$ " could be traced on a phonological level, in the 'accent' of the specific speakers. In the examples of Liu (2002), the “回/买/吃/打/去” in “我回家了”, “我买三个了”, “我吃 
饭了”, “我打二两油了” and “我去公园了” could be considered to have a special stress in the corresponding context. From a pragmatic point of view, these positions are the focus of information.

Wang \& Liu (2006) examined a series of sentence patterns with the same proposition but a different aspect marked by "le", such as:

“不知道她等了多久”, “不知道她等多久了”, “不知道她等了多久了”

What are the differences in the above three sentences? The article gave us three categories from a pragmatic perspective: the reporting category is used to report a piece of information, the narrative category is used to trace past events, the discussing category is used to illustrate objective truths. " $l e_{1}+l e_{2}$ " and " $l e_{2}$ " belong to the "reporting category", "le" belongs to the "narrative category" and the "discussing category". Compared with Liu (2002), the research of Wang \& Huang (2020) adopts a different, stylistic, perspective, but the results are basically the same.

\subsubsection{Tense and Aspect}

Liu (2002) believes that "le" at the end of the sentence has the function of expressing the past tense, but it is a "relative past tense" as we mentioned above. Whether it is in Chinese or in Western languages, "tense" needs a reference point. In English, the reference point of "-ed" is the speaking time, while the reference point in Chinese is twofold, it can be either the speaking time or the time expressed by the time word, in the case where it exists in the sentence. So even though " $1 e_{2}$ " can be used in the past, present and future on the surface, it still carries a "relative past tense" dimension. We quote the example in the article to illustrate:

明年, 我该大学毕业了。(future)

25 万年前, 周口店猿人就知道用火了。(past)

What needs to be pointed out is that all actions either happened in the past or will happen in the future and none happen at the time of speaking. In “我吃了”, is the act of "eating" completed? In fact, we can consider it differently. Because the action happened in the past, it had naturally been completed by the time of speaking. He (2013) also agrees with this view. In addition, some scholars believe that " $l e_{2}$ " is also a kind of aspectual marker (Zhang $\left.\& \mathrm{Lu}, 2011\right)$. Specifically " $l e_{1}$ " marks an action, while " $l e_{2}$ " marks an event and it refers to the content of the entire sentence. The concepts of "tense" and "aspect" are highly intertwined. In fact, as long as we understand that " $l e_{2}$ " has the function of a tense marker, the tense of the action being the past tense, which means completion of an action. Therefore, these two theories have similarities in their interpretation of " $l e_{2}$ ".

Chinese grammatical categories are not necessarily based on contrasts. For instance, the use of the aspectual marker in Chinese is non-mandatory. Therefore, we must step out of the circle of blindly borrowing the research framework of Western linguistics or general linguistics and be clear that the aspect marker of Chinese is not a pure syntactic phenomenon, but a "syntax-pragmatic" pheno- 
menon. In order to explain the use of it, just a few rules on the form of sentences do not suffice. "le" has greater concealed freedom and the implied aspect meaning does not necessarily have to be borne by "le".

Continuous research on " $1 e_{2}$ " has made researchers more aware of its "subjectivity". Language is a communication tool, especially in second language teaching. Therefore, we believe that emphasis on the pragmatic aspect of the use of " $l e_{2}$ " is bound to be of great help to TCSOL.

\subsection{Basis for This Article}

Based on the previous studies above, we accept the premise that " $l e_{1}$ " is an aspectual particle indicating the realization of an action, carrying a relative past tense meaning, while its use is subject to various conditions, including the nature of the predicate, the complement and the appearance of " $l e_{2}$ ". " $l e_{2}$ " is a modal particle which indicates the realization of the state of affairs, it can indicate the appearance of changes or new situations, it has pragmatic functions such as "Please listen to me", it indicates the relative past tense, it has strong subjective close interactivity, it is mostly used in speaking and it is seldom used in news reports and other scenarios.

Based on the characteristics of the teaching of grammar within the context of TCSOL, the theoretical basis of this article is that " $l e$ " is a particle, which means the realization of an action or state. It is used after the verb in the sentence and at the end of the sentence. When " $l e$ " is used at the end of the sentence, the meaning of "change" can be derived from the meaning of "realization", as there are rich pragmatic functions such as "reminder" and "commitment" in communication, indicating a relative past time. In our approach, we merged the two traditional " $l e$ " uses into one, which can be further sub-categorized according to

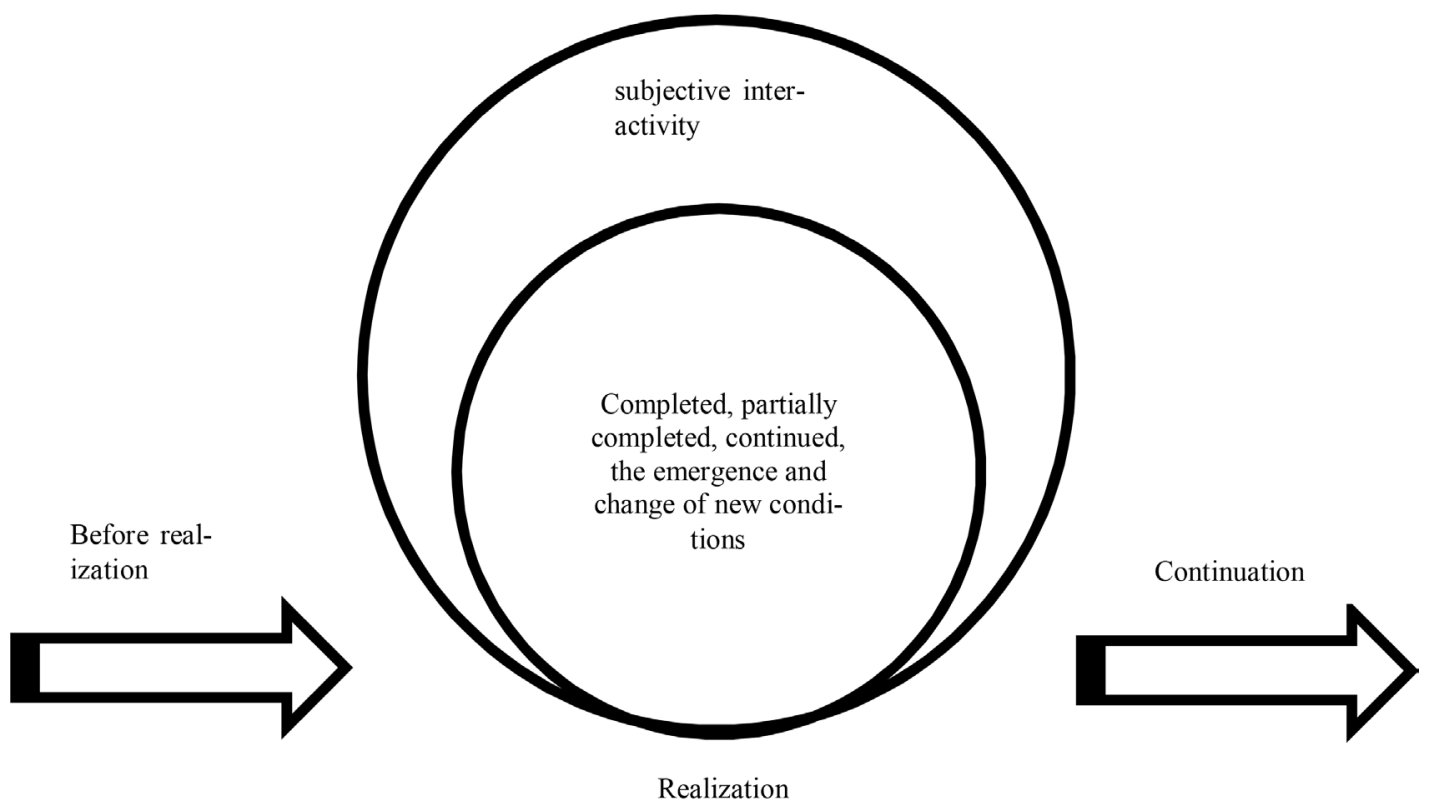

Figure 1. The relationship among different concepts. 
syntactic, semantic and pragmatic functions. This can be shown in Figure 1 above. This article does not follow the traditional expression of "representing the affirmative tone of the realization or completion of the action", because this is not very practical in the context of TCSOL.

\section{Problems in International Chinese Textbooks}

In this article, we selected four popular Chinese textbooks, namely "New Practical Chinese Reader" (Second Edition), "HSK Standard Course", "Learn Chinese with Me", and "Experiencing Chinese" (Basic, Intermediate, Advanced), in order to examine the provided interpretation of the use of "le".

\subsection{Terminology}

As Table 1 below shows, after compiling the above grammatical points of the afore-mentioned textbooks, we believe that it is more appropriate to use "particle" to refer to "le" and " $l e_{2}$ ", as they are neither "auxiliary verbs" nor "dynamic auxiliaries", but grammatical marker with rich grammatical functions. For " $1 e_{2}$ ", the reason why we do not recommend using "modal particle" is that within the context of TCSOL such linguistic terms can be expected to further obscure grammatical points being taught.

\subsection{Analysis of Grammatical Points}

As shown in Table 2 below, this book covers three main uses of "le". However, it is not accurate to say that " $e_{2}$ " only refers to the past, because it can actually express the future, such as in “明天晚上八点我就下飞机了”. Although the absolute time here is "tomorrow", there is reference to a relative past tense. When the time reference is "tomorrow eight o'clock", it is meant that the "getting off the plane" will have been completed before this point of time. Therefore, it refers to a realization of an action.

In addition, in this book, it is shown that "le" is used at the end of a sentence to have both functions of " $e_{1}$ " and " $e_{2}$ ". We believe that this does not enhance comprehension in teaching, so it is difficult for students to truly understand its meaning and we do not recommend introducing this statement to them. Comparing the sentences “他去了” and “我买衣服了”, the author of the textbook, in

Table 1. Terms in the four books.

\begin{tabular}{ll}
\hline Textbook name & Term name \\
\hline "New Practical Chinese Reader" (Second Edition) & $l e_{1}$ Particle \\
& $l e_{2}$ Particle \\
"Learn Chinese with Me" & $l e_{1}$ Dynamic auxiliary \\
& $l e_{2}$ Auxiliary verb \\
"HSK Standard Course" & $l e_{1}$ Particle \\
& $l e_{2}$ Particle \\
"Experiencing Chinese" series & $l e_{1}$ Particle \\
& $l e_{2}$ Modal particle \\
\hline
\end{tabular}


Table 2. Distribution of "le" in "New Practical Chinese Reader" (Second Edition).

\begin{tabular}{|c|c|c|}
\hline Location & Interpretation & Examples \\
\hline $\begin{array}{c}\text { Book } 1 \\
\text { Lesson } 13\end{array}$ & $\begin{array}{l}\text { " } l e_{1} \text { " can be placed after the verb to indicate that someone has } \\
\text { done something; if the verb with " } l e \text { " is followed by an object, } \\
\text { the object usually has quantity, adjectives or pronouns as } \\
\text { attributives. }\end{array}$ & $\begin{array}{l}\text { 我买了五个苹果。 } \\
\text { 大为吃了很多中药。 }\end{array}$ \\
\hline $\begin{array}{c}\text { Book } 2 \\
\text { Lesson } 15\end{array}$ & $\begin{array}{l}\text { " } l e_{2} \text { " affirms the completion or realization of things; only } \\
\text { indicates the past; but the past events do not necessarily use } \\
\text { " } l e_{2} \text { ". }\end{array}$ & $\begin{array}{l}\text { 你去哪儿了? } \\
\text { 你买什么了? } \\
\text { 我去商场了。 } \\
\text { 我买衣服了。 }\end{array}$ \\
\hline $\begin{array}{c}\text { Book } 2 \\
\text { Lesson } 15\end{array}$ & $\begin{array}{l}\text { " } l e \text { " at the end of the sentence has both " } l e_{1} \text { " and " } l e_{2} \text { " unctions. } \\
\text { It indicates the completion or realization of an action and the } \\
\text { affirmation of completion or realization. }\end{array}$ & $\begin{array}{l}\text { 我懂了。 } \\
\text { 他去了。 } \\
\text { 刚才宋华来了。 }\end{array}$ \\
\hline $\begin{array}{c}\text { Book } 2 \\
\text { Lesson } 23\end{array}$ & “要……了” means the action is about to happen. & 天气要热了。 \\
\hline $\begin{array}{c}\text { Book } 2 \\
\text { Lesson } 24\end{array}$ & $\begin{array}{l}\text { Used at the end of a sentence to indicate a change of situation } \\
\text { or the emergence of a new situation. It is often used in } \\
\text { adjective predicate sentences or sentences containing “有” and } \\
\text { “是”. }\end{array}$ & $\begin{array}{c}\text { 现在天气冷了。 } \\
\text { 你舅妈也开始用电脑 } \\
\text { 了。 }\end{array}$ \\
\hline $\begin{array}{l}\text { Volume } 3 \text {, } \\
\text { Lesson } 30\end{array}$ & $\begin{array}{l}\text { Used behind noun phrases, subject-predicate phrases, etc. to } \\
\text { indicate changes in situations or the emergence of new } \\
\text { situations. This kind of sentence is usually used to remind or } \\
\text { attract the attention of others. }\end{array}$ & 他八岁了。 \\
\hline $\begin{array}{c}\text { Book } 4 \\
\text { Lesson } 43\end{array}$ & “V/A + 死 + 了” indicates the psychological degree. & 我饿死了。 \\
\hline
\end{tabular}

the first example, meant that “去” is a bare verb and the original sentence “should” be “他去了 $\left.{ }_{1}\right\}_{2}$ ”. In the second example, with the verb “买” carrying an object, the original sentence can be “我买 $\left(了_{1}\right)$ 衣服了 ${ }_{2}$ ”. However, we believe that we could, more efficiently, explain the two sentences in one paradigm. The use of "le" in these two sentences means that the behavior has been realized. In this manner, there is no need to add unnecessary and obscure information that does not facilitate the students' understanding. If we really use the proposed " $l e_{1}$ $+l e_{2}=l e_{3}$ ", then in fact many " $l e_{2}$ " sentences can be included in this category, as, according to the previous review, we know in sentences with co-occurring "le" particles, the reason why most " $l e_{1}$ " can often be omitted is because " $l e_{2}$ " provides “tense" or “tone”. For example, “我去 $\left(\zeta_{1}\right)$ 商场了 2 ”. This is an indication that traditional grammatical approaches need to be adapted in order to become effective within a pedagogical context.

According to the textbook, " $l e_{2}$ " is used after noun phrases and subject-predicate phrases to indicate change and to remind or attract others' attention. We believe that the introduction of this usage is very good, suitable for the needs of communication. It includes the semantic level, indicating the change of the situation, and the pragmatic function level, which refers to drawing the listener's attention. We believe that the sentence could be somewhat refined and introduce more detailed pragmatic functions, such as "reminder", "commitment", "recommendation” and so on. For examples, “吃饭了” (reminder), “别去了” (recommenda- 
tion) “再见了” (promise), etc. These usages are not covered by traditional explanations and they do not indicate changes. We should distinguish this usage from those of "realization" or "change" of actions or states.

As Table 3 below shows, we believe that this set of textbooks is well-arranged in terms of the explanation of "le", which is more consistent with our approach. Its purpose is to compile the two " $l e_{1}$ " and " $l e_{2}$ " into one " $l e$ ". This is probably a more effective approach. It should be noted that there are two different examples in Book 1 Lesson 5: “她今年 50 岁了” and “她女儿今年 20 岁”. Since both mean "change", why does one carry "le" and the other doesn't? In view of such a question that students may ask, the teacher needs to have a way to explain. According to the existing research, the "le" in the first sentence puts age in an axis, while the second sentence is just a simple and static statement of the fact. There is no significant difference between them. In Book 3, Lesson 5, it is mentioned that $l e$ "indicates the emergence of a new situation", with all the example sentences being in the present tense. We think it would be better to also explain to students the past and future situations of “le". For example: “我明年就不住在这 儿了”. In fact, the similar sentence “我明天不能和你们出去玩了” has already appeared in the text. The important thing is that there are many pragmatic uses in this textbook, which are presented to students in detail in different formats, such as" 都…… 了” “要…… 了” “别提多…… 了”. We believe that this is very useful, communicative approach that reinforces students' understanding.

Regarding the textbook shown in Table 4 that follows, we have pointed out the problem of terminology. In addition, in this book we can notice some inconsistency between the example sentences and the interpretation of the grammar

Table 3. Distribution of "le" in"HSK Standard Course".

\begin{tabular}{|c|c|c|}
\hline Location & Interpretation & Examples \\
\hline $\begin{array}{c}\text { Book } 1 \\
\text { Lesson } 5\end{array}$ & $\begin{array}{l}\text { "le" is used at the end of a sentence to indicate the appearance } \\
\text { of changes or new circumstances. }\end{array}$ & $\begin{array}{l}\text { 你女儿几岁了? } \\
\text { 我朋友的女儿今年 } \\
\text { 四岁了。 } \\
\text { 他女儿今年 } 20 \text { 岁。 }\end{array}$ \\
\hline $\begin{array}{c}\text { Book } 1 \\
\text { Lesson } 14\end{array}$ & $\begin{array}{l}\text { "le" indicates occurrence or completion: } 1 \text {. Used at the end of a } \\
\text { sentence. } 2 \text {. It is used to have an object after a verb, and the } \\
\text { object after the verb must have an attributive before the object, } \\
\text { such as a quantifier or an adjective, a pronoun, etc. }\end{array}$ & $\begin{array}{l}\text { 我去商店了。 } \\
\text { 他买了一点儿苹果。 } \\
\text { 你看见了几个人? }\end{array}$ \\
\hline $\begin{array}{c}\text { Book } 2 \\
\text { Lesson } 10\end{array}$ & “不要……了” “别……了”means prohibition and dissuasion. & $\begin{array}{l}\text { 不要看电视了 } \\
\text { 别看书了。 }\end{array}$ \\
\hline $\begin{array}{c}\text { Book } 2 \\
\text { Lesson } 15\end{array}$ & $\begin{array}{l}\text { “要……了” indicates the state of the action, which is about to } \\
\text { happen. }\end{array}$ & 要下雨了。 \\
\hline $\begin{array}{c}\text { Book } 2 \\
\text { Lesson } 15\end{array}$ & $\begin{array}{l}\text { “都...... 了” can mean “already”, and usually contains a tone of } \\
\text { emphasis or dissatisfaction. }\end{array}$ & 都等她半个小时了。 \\
\hline $\begin{array}{c}\text { Book } 3 \\
\text { Lesson } 5\end{array}$ & $\begin{array}{l}\text { The modal particle "le" is used at the end of a declarative } \\
\text { sentence to indicate that the situation has changed or a new } \\
\text { situation has occurred. }\end{array}$ & $\begin{array}{l}\text { 我现在没钱了。 } \\
\text { 我前几天有点儿发 } \\
\text { 烧, 现在好多了。 }\end{array}$ \\
\hline $\begin{array}{l}\text { Lesson } 1 \text { on } \\
\text { Book } 6\end{array}$ & $\begin{array}{l}\text { “别提多....... 了” means that the degree is very deep, and there } \\
\text { is no need to go into details. With an exaggerated tone. }\end{array}$ & $\begin{array}{l}\text { 这个人办事, 别提多 } \\
\text { 负责了。 }\end{array}$ \\
\hline
\end{tabular}


points. For example, in Lesson 13 of Book 2 it is said that " $l e_{1}$ " is used at the end of a word to indicate the realization or completion of an action, but the example sentence given is “我吃早饭了”, which is clearly the usage of “ $1 e_{2}$ ”. The sentences in the text such as “早饭你吃了什么? ” “我喝了一杯牛奶” “吃了两个鸡蛋” “我喝了一碗粥”, etc. are obviously typical “le” 1 ” usage.

This set of textbooks does not list the usage of " $l e_{2}$ " to indicate the realization of the action, but only the usage to indicate the new situation, which we think is not adequate. Used at the end of the sentence, the basic function of " $l e_{2}$ " is to express the realization of an action or state, which is the same as " $1 e_{1}$ ". The expression of the emergence of a new situation is an extended usage. According to the "principle of cooperation" of communication, an effective conversation must provide new information. For students, the explanation of the language points in the book cannot solve the language phenomenon encountered. For example, “你 买什么了?” This does not mean the emergence of a new situation. Especially when students encounter two "did" co-occurrences, they will be even more confused, such as “你买了什么了? ”.

In addition, there is the problem of incoherent interpretation of language points. For example, “别忘了拿作料来” in Lesson 13 of Book 3 and “等到严重 就晚了! ” in Lesson 14. Students cannot understand these two sentences based on their existing knowledge. In fact, one of these two example sentences can be explained by the subjective interactivity function of " $l e_{2}$ ", and the other is a typical usage of “le”. The sentence “别忘了拿作料来” can be converted to “拿作料 来, 别忘了! ” In this case, “别忘了” is a parenthesis, which represents the pragmatic function of "to remind". Students can understand this sentence by learning this phrase individually. The “le $e_{2}$ " in the sentence “等到严重就晚了” indicates the realization of the behavior.

The grammar point "adverb ke indicates emphasis" in Lesson 18 of Book 3, in

Table 4. Distribution of "le" in "Learn Chinese with Me".

\begin{tabular}{cll}
\hline Location & Interpretation & Examples \\
\hline Book 2 & Auxiliary verbs, which indicate new situations or changes, are & 巴西队赢了。 \\
Lesson 5 & often used at the end of sentences. & 杰克也喜欢跳舞 \\
& & 了。 秋天树叶黄了。 \\
Book 2 & “太…..了” means surprise, fear, gratitude, regret, etc. & 这儿的风景太美 \\
Lesson 6 & & 了! \\
& & 太好了! \\
Book 2 & As a dynamic auxiliary, “le” is used after a verb to indicate & 吃了。 \\
Lesson 13 & realization or completion. If there is an object after the verb, the & 我吃早饭了。 \\
& object after the verb must have an attributive before the object, & \\
& such as a quantifier, an adjective, or a pronoun. & \\
Book 3 & “Adjective + 极了” means a high degree. & 风景美极了。 \\
Lesson 6 & &
\end{tabular}


fact, “ $k e$ ” here serves as an adverbial, which can be replaced with “相当” or “太” without changing the meaning. After studying this item, students still don't know what the "le" in these sentences means and why they should use it. Our suggestion is the same as previously, that is, to add more pragmatic functions to the textbook.

As Table 5 below shows, this set of textbooks is also relatively complete in the arrangement of grammar points, covering the common usage of "le". However, according to our definition, the distinction between " $l e_{1}$ " and " $l e_{2}$ " in the book is also unnecessary, especially for the interpretation of the term "express affirmative tone", which is usually hard to understand by students. We recommend merging them. One thing worth noting is that this textbook proposes some

Table 5. Distribution of "le" in "Experiencing Chinese" (Basic, Intermediate, Advanced).

\begin{tabular}{|c|c|c|}
\hline Location & Interpretation & Examples \\
\hline $\begin{array}{l}\text { Basic Course } \\
\text { (Part 1) } \\
\text { Lesson } 13\end{array}$ & $\begin{array}{l}\text { “太..... 了” Expressing praise and exclamation in the exclamatory } \\
\text { sentence, but also expressing excessive and dissatisfied attitude }\end{array}$ & $\begin{array}{l}\text { 太好了! } \\
\text { 太难了! }\end{array}$ \\
\hline $\begin{array}{l}\text { Basic Course } \\
\quad(\text { Part } 1) \\
\text { Lesson } 14\end{array}$ & “对了” can be used to change the topic in a conversation & $\begin{array}{l}\text { 对了,今天 } 12 \\
\text { 号吗? }\end{array}$ \\
\hline $\begin{array}{l}\text { Basic Course } \\
\qquad \text { (Part 1) } \\
\text { Lesson } 16\end{array}$ & $\begin{array}{l}\text { "Verb }+了 \text { " means the realization or completion of a behavior. If } \\
\text { there is an object after the verb, the object after the verb must have an } \\
\text { attributive before the object, such as a quantifier or an adjective, a } \\
\text { pronoun, etc. }\end{array}$ & $\begin{array}{l}\text { 我买了一件 } \\
\text { 毛衣。 }\end{array}$ \\
\hline $\begin{array}{l}\text { Basic Course } \\
\qquad(\text { Part } 1) \\
\text { Lesson } 18\end{array}$ & $\begin{array}{l}\text { The modal particle "le" is used at the end of a sentence to indicate: } 1 \text {. } \\
\text { Affirmative tone. } 2 \text {. The speaker indicates that a certain behavior has } \\
\text { occurred. } 3 \text {. The speaker indicates that the situation has occurred } \\
\text { within a certain period of time. (Often in the form of words with time) }\end{array}$ & $\begin{array}{l}\text { 你昨天去哪 } \\
\text { 儿了? } \\
\text { 马克昨天去 } \\
\text { 图书馆了。 }\end{array}$ \\
\hline $\begin{array}{l}\text { Basic Course } \\
\qquad(\text { Part } 1) \\
\text { Lesson } 19\end{array}$ & “别……了” means discourage or prohibit & 别睡觉了! \\
\hline $\begin{array}{l}\text { Basic Course } \\
\quad(\text { Part } 1) \\
\text { Lesson } 20\end{array}$ & $\begin{array}{l}\text { “死” is used as the complement of the result, indicating a high degree } \\
\text { or excessive, and often co-occurs with “a" }\end{array}$ & 我忙死了! \\
\hline $\begin{array}{l}\text { Basic Course } \\
\qquad(\text { Part } 1) \\
\text { Lesson } 23\end{array}$ & $\begin{array}{l}\text { “该...... 了” means that the possible outcome can be reasonably } \\
\text { predicted }\end{array}$ & 该上课了! \\
\hline $\begin{array}{l}\text { Basic Course } \\
\qquad(\text { Part 2) } \\
\text { Lesson } 31\end{array}$ & “要……了” means the action is about to happen & $\begin{array}{l}\text { 他要来北京 } \\
\text { 了。 }\end{array}$ \\
\hline $\begin{array}{l}\text { Basic Course } \\
\qquad \text { (Part 2) } \\
\text { Lesson } 36\end{array}$ & “Adjective/Verb + 极了” means high degree & 感觉好极了! \\
\hline $\begin{array}{l}\text { Basic Course } \\
\qquad \text { (Part 2) } \\
\text { Lesson } 36\end{array}$ & $\begin{array}{l}\text { The modal particle "le" is used at the end of a sentence to indicate } \\
\text { change }\end{array}$ & $\begin{array}{l}\text { 我累了。 } \\
\text { 我想回国了。 }\end{array}$ \\
\hline $\begin{array}{l}\text { Basic Course } \\
\qquad \text { (Part 2) } \\
\text { Lesson } 36\end{array}$ & $\begin{array}{l}\text { “别提了” means that the speaker does not want to talk about } \\
\text { something or expresses unhappiness. }\end{array}$ & $\begin{array}{l}\text { 别提了! 我的 } \\
\text { 钱包丢了。 }\end{array}$ \\
\hline
\end{tabular}


discourse and pragmatic uses of “le”, such as “别提了”, “对了”, etc. which are very suitable for the communication needs of Chinese learners.

To sum up the previous analysis of the four textbooks analysed in this paper, we recommend merging the traditional " $l e_{1}$ " and " $l e_{2}$ " in TCSOL, to include "realization of an action or state" covering different syntactic positions, as the concept of "realization" itself contains many states such as the occurrence, completion and continuation of actions. The use of " $l e_{2}$ ", meaning "affirmative tone", and the " $l e_{1}+l e_{2}=l e_{3}$ " can be avoided. We suggest adding different pragmatic functions of "le" at the end of the sentence and emphasizing the difference between using "le" and not using "le" in the example sentences. Moreover, it is useful to explain the hidden laws of "le" from the perspectives of writing types, lexical reasons and writing style.

\section{Some Suggestions on the Pedagogical Grammar of "Ie"}

On the whole, a pedagogically-oriented grammar should integrate the principles of syntax and pragmatics and adopt the principle of "easy to learn, step by step" approach. In the elementary stage of teaching, we should avoid the introduction of the co-occurrence of the two "le" uses. As we have already mentioned this distinction does not facilitate the understanding of the actual use of "le". Below are the four dimensions that we proposed in terms of the teaching of " $l e$ ".

\subsection{Indicating the Realization of Behavior or State}

As Table 6 shows, At an elementary stage of introducing "le" to students, like with all other grammatical phenomena, we move from the shallower to the deeper, from simple to more complex uses. We can teach the fixed sentence pattern

Table 6. Suggested arrangements based on "realization".

\begin{tabular}{|c|c|}
\hline Grammar item description & Example sentences \\
\hline $\begin{array}{l}\text { Used after a verb, adjective, or noun phrase to indicate the realization } \\
\text { of an action or state. (a) It can be used after a verb or adjective in a } \\
\text { sentence, and it can also be used at the end of a sentence. When in a } \\
\text { sentence, the object after the verb is usually preceded by an attributive, } \\
\text { such as a quantifier or an adjective, a pronoun, etc. At the end of the } \\
\text { sentence, emphasize the contrast between behavior and the status } \\
\text { before and after "realization", that is, the emergence or change of new } \\
\text { situations. (b) Sometimes it can appear at both the end of a word and } \\
\text { the end of a sentence at the same time }\end{array}$ & $\begin{array}{l}\text { 我买了三本书。 } \\
\text { 他昨天到中国了。 } \\
\text { 三个月了。 } \\
\text { 花红了。 } \\
\text { 明天开学了。 } \\
\text { 要下雨了。 } \\
\text { 我已经买了平果了。 }\end{array}$ \\
\hline $\begin{array}{l}\text { “Adjective + 死了” } \\
\text { “太……了” } \\
\text { “要……了” } \\
\text { “不要/别……了” } \\
\text { “都……了” } \\
\text { “该……了” }\end{array}$ & $\begin{array}{l}\text { 今天热死了。 } \\
\text { 太贵了。 } \\
\text { 要开学了。 } \\
\text { 别开玩笑了。 } \\
\text { 都三点了。 } \\
\text { 该你了。 }\end{array}$ \\
\hline “.......怎么了” means asking about the situation & 你最近怎么了？ \\
\hline Pivotal sentences and sentences with verbal constructions in series & $\begin{array}{l}\text { 我去图书馆借了两本书 } \\
\text { 上学期我们请了他来给我 } \\
\text { 们做讲座。 }\end{array}$ \\
\hline
\end{tabular}


with "le" first, then teach the "le" uses, and then teach the " $l e_{2}$ " uses.

\subsection{Subjective Communicative Function and Textual Function}

At an intermediate stage, this function of "le" can be introduced and presented gradually at different points in different lessons. They are not annotated as a special grammar point, but only appear in the text with their interpretation. Examples are shown in Table 7 below.

\subsection{The Sentence Pattern that May Need "Ie"}

As the awareness of students of more grammatical phenomena rises, more uses of le as a necessary particle can be introduced. In Table 8 that follows, we can see two such examples.

\subsection{The Situation of Exclusion}

One last suggestion in the teaching of "le" is to take advantage of students" wrong productions or instances where " $l e$ " cannot appear as shown in Table 9 below, in order to discuss its exclusion, in different lessons. In this way, students will gradually acquire a better understanding of where "le" must be avoided.

\section{Epilogue}

Within a TCSOL context, maintaining a good balance between syntax, semantics and pragmatics, while providing sufficient explanation for various grammatical items is very important. Thus, students can not only recognize what they listen

Table 7. Suggested arrangements based on communicative functions and textual functions.

\begin{tabular}{ll}
\hline Grammar item description & Example sentences \\
\hline “le means request, order, praise, urge, reminder, etc. It 再见了。 \\
has the meaning of asking others to listen, but it does 上课了! \\
not have the meaning of “achievement, completion, 你看看,都几点了? \\
change, emergence of new circumstances”, etc. & 开饭了 \\
& 我走了。 \\
& 我可不干了。 \\
& 多了，多了，喝不完。 \\
& 卖苹果了! \\
Pure tonality, can be replaced with “la” & 对不起了! \\
“对了” to start a topic & 他的汉语说得可好了! \\
If the topic remains the same, even if a sentence is over, 我下车后回家了, 打开冰箱了, 拿出一瓶 \\
the ending “le” is generally not needed & 这个你当然懂了。 \\
\hline
\end{tabular}

Table 8. The sentence patterns that may need "le".

\begin{tabular}{cl}
\hline Grammar item description & Example sentences \\
\hline “Ba" sentence & 他把作业写完了。 \\
“Bei” sentence & 西瓜被他吃完了。 \\
\hline
\end{tabular}


Table 9. Words or patterns that reject " $l e$ ".

\begin{tabular}{|c|c|}
\hline Grammar item description & Example sentences \\
\hline $\begin{array}{l}\text { Words that do not mean "change", such as "feel, be, like, } \\
\text { hope, act, and talent", etc. }\end{array}$ & $\begin{array}{l}\text { *后来他变了很糟糕。 } \\
\text { *他们整个下午一直坐在了海边。 } \\
\text { *十年前, 那儿有了一户人家。 } \\
\text { *他八点才到家了。 }\end{array}$ \\
\hline Indicates frequent action & *我小时候每年都去了上海过年 \\
\hline “是 ……的” & *我(是)去年暑假来了。 \\
\hline “在” means the action is happening & $\begin{array}{l}\text { *昨天你给我打电话的时候, 我在看 } \\
\text { 电视了。 }\end{array}$ \\
\hline $\begin{array}{l}\text { When the object is a predicate word, you cannot use “le" after } \\
\text { the predicate verb. Except for words such as “进行” and “作”. }\end{array}$ & $\begin{array}{l}\text { *上个星期, 我们开始了学习新课。 } \\
\text { 他们在会后进行了讨论。 }\end{array}$ \\
\hline
\end{tabular}

to and read, but also acquire the ability to speak and write. In addition, the relationship between a "simplified" and a "detailed" analysis of grammatical items must be balanced. We very much agree with the statement by Liu (2001) "In teaching, it's important to learn to use "le", without having to investigate which "le" has been used, because the aspectual particle " $l e$ " and the modal particle "le" have the same grammatical meaning". We also suggest that a combination of the two " $l e$ " uses is more effective. The innovation of this article is the proposal of a unified approach to the interpretation of " $l e$ " within the theory of "realization", the avoidance of the concepts of "complete" and "change", of " $l e_{1}+l e_{2}=l e_{3}$ " and of the idea that " $l e_{2}$ " indicates the tone". Simultaneously, we propose the increase of the subjective communicative uses of "le", the distinction between the meanings of sentence patterns and word meanings and the unification of related terms. The advantages of such an approach include that the conceptual difference between the two uses of "le" is eliminated, making it easier for students to understand, the connection between various usages help cohesion and clarity and strengthen competence in the four skills of "listening, speaking, reading and writing" to boot.

\section{Conflicts of Interest}

The authors declare no conflicts of interest regarding the publication of this paper.

\section{References}

Deng, Y. Y. (2021). On the Semantic Expression of the Modal Particle le at the End of the Sentence. The Culture of Chinese Characters, 1, 69-73.

Fan, X. L. (2020). How the Integral Grammatical Attributes of a VP Condition the Distribution of Verbal le. Chinese Teaching in the World, 2, 185-200.

Grice, P. (1989). Studies in the Way of Words. Harvard University Press.

He, W. B. (2013). On the Subjectivity of the Modal Particle le. Studies in Language and Linguistics, 1, 10-18.

Jin, L. X. (2002). The Tense and Aspect Meaning of le and Its Syntactic Conditions. Chi- 
nese Teaching in the World, 1, 34-43.

Lin, R. W. (2017). Discuss the Tense and Aspect of le Again. Studies of the Chinese Language, $1,3-21$.

Liu, X. N. (1988). The Grammatical Meaning of le in Modern Chinese. Studies of the Chinese Language, 5, 321-330.

Liu, X. N. (2002). The Grammatical Meaning and Explanation of le at the End of Modern Chinese Sentences. Chinese Teaching in the World, 3, 70-79.

Liu, Y. H. (2001). Practical Modern Chinese Grammar (2nd ed., pp. 248-249). Commercial Press.

Shen, J. X. (2003). Three Domains of Complex Sentences: Action, Knowledge and Speech. Studies of the Chinese Language, 3, 16-29.

Wang, G. Q., \& Liu, Y. L. (2006). Le Sentences with Identical Proposition. Chinese Language Learning, 25-30.

Wang, J., \& Huang, M. D. (2020). The Restrictive Factors of the Sentence Formation Ability of $l e_{1}$ and $l e_{2}$. Chinese Language Learning, 1, 2-13.

Xiao, Z. Y., \& Shen, J. X. (2009). Three Domains of the Sentence Final Particle $1 e_{2}$. Studies of the Chinese Language, 6, 518-576.

Zhang, G. X., \& Lu, J. (2011). The Path and Consequences of the Regrammaticalization of the Particle le. Linguistic Sciences, 4, 337-352. 